\title{
Emission Scenario Assessment of Gasohol Reformulation Proposals and Ethanol Use in the Metropolitan Area of São Paulo
}

\author{
L.D. Martins* and M.F. Andrade
}

Department of Atmospheric Sciences, Institute of Astronomy, Geophysics and Atmospheric Sciences, University of São Paulo, Brazil

\begin{abstract}
The frequent episodes of high concentrations of ozone and of inhalable particulate matter occurring in the Metropolitan Area of Sao Paulo (MASP) are primarily associated with vehicle emissions. The objective of this study was to evaluate the impact of the use of reformulations of the gasoline-ethanol blend known as gasohol and of ethanol on the ozone formation. A three-dimensional photochemical model was employed to estimate the sensitivity of ozone and evaluate the implementation of emission scenarios, considering various fuel formulations, in the MASP. The base case ozone concentrations were consistent with the observations over six air quality monitoring stations located in the MASP, suggesting that the model can be used to evaluate the impact that various emission scenarios would have on ozone levels. Six scenarios were analyzed; scenarios 1 to 5 involved reductions in compounds found in gasohol in various proportions compared with the base emission inventory and scenario 6 specified that the entire light duty fleet would burn pure ethanol. In scenario 3 (reductions in olefins, aromatics and benzene) and scenario 5 (reductions in the five species that are associated with higher ozone sensitivity), ozone concentrations were below the national standard only at the air quality monitoring stations (not domain-wide). Our results suggest that implementing scenario 6 would improve air quality in the MASP.
\end{abstract}

\section{INTRODUCTION}

The Metropolitan Area of São Paulo (MASP) is classified as a megacity. It is the largest urban area in South America, with a population of over 17 million people and a fleet of approximately 7.8 million vehicles, the latter being responsible for more than $90 \%$ of all carbon monoxide (CO), hydrocarbon $(\mathrm{HC})$ and nitrogen oxide $\left(\mathrm{NO}_{x}\right)$ emissions in the area [1]. The Programa de Controle da Poluição do Ar por Veículos Automotores (PROCONVE, Program for the Control of Air Pollution Emission by Motor Vehicles), implemented in 1989, established emissions standards for all new vehicles sold in Brazil. A decrease in the levels of pollutants, principally $\mathrm{CO}$, was subsequently observed $[2,3]$. Nevertheless, ozone and inhalable particulate matter levels routinely exceed the Brazilian national ambient air quality standards

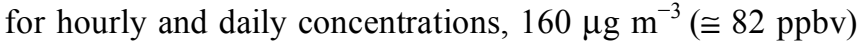
and $150 \mu \mathrm{g} \mathrm{m}^{-3}$, respectively $[4,5]$.

The vehicle fleet in the MASP is unique in that ethanol is used as a fuel on a large scale: $14.5 \%$ of the vehicles run on hydrated ethanol $(95 \% \mathrm{v} / \mathrm{v})$; and $69.5 \%$ run on a mixture containing $75-78 \%$ gasoline and $22-25 \%$ anhydrous ethanol, which is referred to as gasohol. Therefore, ethanol accounts for approximately $34 \%$ of the fuel burned by the fleet in the MASP. Motorcycles and heavy-duty vehicles constitute approximately $9.3 \%$ and $5.8 \%$ of the fleet, respectively [6]. Flex-fuel vehicles (running on either gasohol or ethanol) and

*Address correspondence to this author at the Department of Atmospheric Sciences, Institute of Astronomy, Geophysics and Atmospheric Sciences, University of São Paulo, Brazil; Tel: 55113091 4713; Fax: 55113091 4714; E-mail: leiladro@model.iag.usp.br vehicles converted to burn compressed natural gas were recently introduced into the fleet. In the MASP, as in other large metropolitan areas in Brazil, the sulfur content of the diesel fuel sold $(350 \mathrm{ppm})$ is considerably lower than that of the diesel fuel sold in other areas of the country (2000 ppm) [1]. In short, the MASP features an unconventional mixture of vehicle types and fuel types, and this profile has evolved dramatically in recent years. Also more than $49.5 \%$ of MASP fleet is older than 10 years. The typical condition of traffic in São Paulo has higher emissions between 7:00 and 9:00 am, and 5:00 to 9:00 pm (Martins ES\&T 2006).

The adverse effects of ozone on human health, vegetation and materials are well known and have been described in various studies, some of which were conducted in the MASP $[7,8]$. Gaining an understanding of pollution events is highly relevant to the formulation of control strategies, and the use of air quality models is an appropriate means of achieving this objective. Reducing ozone levels is important not only for the MASP but also for neighboring cities that are affected by precursor emissions generated by the megacity.

In cities where vehicle emissions are a major source of pollutants, there is a real need for strategies aimed at improving air quality. Such strategies might involve overall reductions in vehicle emissions and the use of reformulated fuels, as well as the management, inspection and maintenance of vehicles used for public transportation. Air quality models have been used to evaluate the impact of vehicle emission control programs in the MASP [3,9]. However, the focus of those studies was the analysis of emission scenarios involving the implementation of programs designed to control total emissions of $\mathrm{CO}, \mathrm{NOx}(\mathrm{NO}+\mathrm{NO} 2)$ and $\mathrm{HC}$. The aim of the present study was to evaluate the impact that the implementation of various emissions scenarios with different fuel for- 
mulations would have on ozone levels in the MASP. Some of these scenarios were based on the proposals to reformulate gasoline in Brazil (targets for 2007 and 2009), and others were based on the use of the gasoline formulations currently marketed in California (USA) and in the European Union. A scenario in which the entire light-duty fleet burns only hydrated ethanol was also tested. The issue of using hydrated ethanol as an alternative to gasoline is currently under debate. Various authors have evaluated the potential impacts of such a change [10-12]. In Brazil, ethanol came to be used extensively as a vehicle fuel in late 1980s. In fact, ethanol-burning vehicles accounted for half of the fleet in the 1990s. For economic reasons related to the cost of producing sugar cane, ethanol (anhydrous or hydrated) accounts for $14.5 \%$ of the vehicle fuel currently consumed in Brazil, compared with $28.3 \%$ for gasoline (Brazilian National Petrol Agency - ANP, http://www.anp.gov.br).

In the present study, we used the California Institute of Technology (CIT) photochemical Eulerian model [13-15] to perform a base case simulation of air quality over São Paulo and six simulations with different emissions scenario to study the impact of potential future fuel formulations on air quality of São Paulo.

\section{METHODS}

\section{Measurements}

In the MASP, the national air quality standard for ozone ( $\cong 82 \mathrm{ppbv}$ for 1 hour) was exceeded on 60 days in the year in 2004. Fig. (1) presents the September time series of ozone concentrations observed at six air quality stations located in the MASP. The study period was from September 6 to September 10 of 2004. During this period, the observed ozone concentration peak was $132 \mathrm{ppbv}$ in the downtown area and
$136 \mathrm{ppbv}$ in the southeastern region of the city. This was characterized as an ozone event with high concentrations.

The meteorological conditions in the period were characteristic of springtime weather in the MASP, with clear skies and no precipitation. On September 6, a high-pressure system developed over the MASP and remained stationary for approximately 4 days. This system, together with light winds, higher temperatures and increased solar radiation, provided ideal conditions for ozone production.

\section{Model}

The CIT Eulerian photochemical model was used to simulate the ozone event. The basis of the model is the atmospheric diffusion equation, which is composed of three modules: meteorology, emissions and chemistry. The gaseous chemical mechanism employed in the chemistry module was the 1999 California Statewide Air Pollution Research Center (SAPRC99) photochemical mechanism developed by Carter [16]. Three basic types of chemical species are treated by mechanism: inorganic species; explicit organic species; and organic species, lumped according to the reactivity and structure of compounds. A total of 90 groups (seventy reactive species) of inorganic and organic species are treated by the mechanism, each group being represented by a code.

Solar radiation is an important parameter in photochemical kinetics. Diurnal eddy diffusion coefficients were parameterized according to total solar radiation and wind velocity. Photolysis rates were calculated using Peterson's actinic flux estimates. Therefore, for ultraviolet solar radiation during the modeled period, clear sky conditions were assumed $[17,18]$.

The CIT model was applied to a domain from $24.2^{\circ} \mathrm{S}$ to $22.9^{\circ} \mathrm{S}$ and from $48^{\circ} \mathrm{W}$ to $45^{\circ} \mathrm{W}$. The surface domain was composed of a grid system of $1800(60 \times 30) 5 \times 5-\mathrm{km}$ cells.

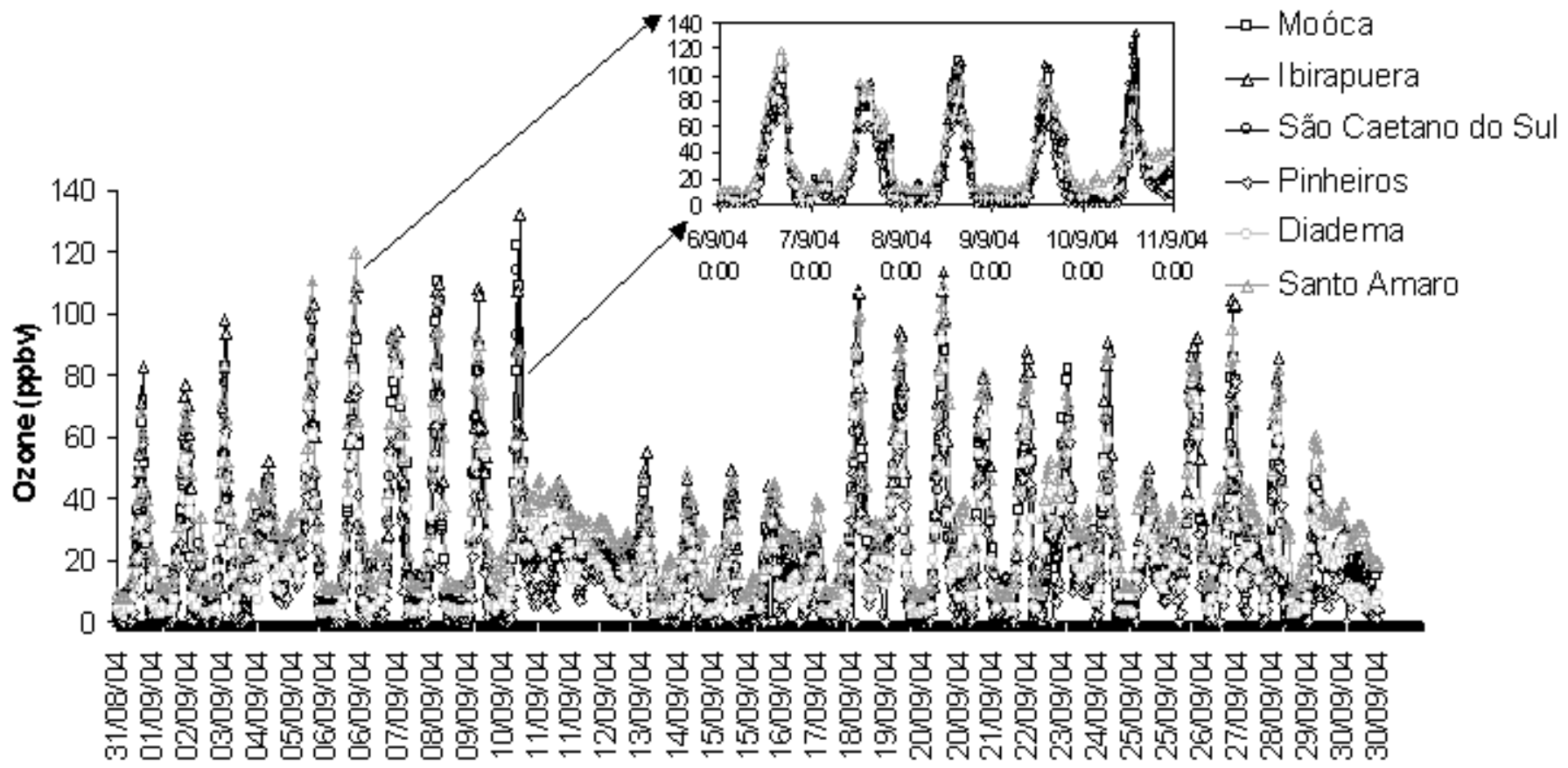

Fig. (1). Time series plot of ozone concentrations observed at MASP air quality stations in September of 2004. 
In the vertical direction, the area was divided into five layers, delineated in such a way that the resolution was greater near the surface. The model top was at an altitude of $2300 \mathrm{~m}$, and the top layer was divided into sub-layers of $80.5,241.5,322$, 759 and $897 \mathrm{~m}$.

The input data used in the model calculations in order to solve the atmospheric diffusion equation were as follows: the meteorological variables (temperature, absolute humidity, solar and ultraviolet radiation, mixing-layer height and threedimensional wind fields); the topographical characteristics (including surface roughness); and, for initial and boundary conditions, the emission rates of the chemical species and the air-quality data. The meteorological fields were obtained from observational data provided by CETESB and Station Metereological named IAGUSP and from meteorological simulations performed using the Brazilian version of the Regional Atmospheric Modeling System (RAMS), version 5.02 , the specifications of which can be found at the site: http://www.cptec.inpe.br/brams/ [19].

The prognostic values and the observational data were interpolated based on the weighted average procedure described by Goodin et al. [20]. Initial and boundary conditions were based on pollutant concentrations measured at CETESB air quality stations [1]. In addition, hourly concentrations of routinely monitored gas-phase pollutants, including ozone, $\mathrm{NO}, \mathrm{NO}_{2}$, sulfur dioxide $\left(\mathrm{SO}_{2}\right), \mathrm{CO}$, and all volatile organic compounds (VOCs) except methane, were interpolated for initial and surface boundary conditions, also based on the weighted average procedure. A spin-up period of 1 day was applied to minimize the importance of the initialization process during the simulations. A complete description of the methodology used to obtain the meteorological fields and initial conditions can be found in SánchezCcyollo et al. [3].

The emission inventories for $\mathrm{HC}, \mathrm{NO}_{x}, \mathrm{CO}$ and $\mathrm{SO}_{2}$ in the base-case simulations were compiled from the CETESB air quality report for the year 2004 [6] and are presented in Table 1. These inventories were spatially and temporally distributed throughout the MASP and were adjusted for emission values. These adjustments were based on pollutant concentrations measured at air quality stations located in the MASP, as well as on the works of Andrade et al. [21] and Vivanco and Andrade [22], which showed the necessity of making these adjustments. The pollutant concentration ratios were considered factors of correction in the emissions profile used in the model. It should be borne in mind that the emissions inventory available for the MASP is relative to the total emissions of pollutants for one year and therefore does not take daily variations into account. The mean adjusted factors were 1.44 for VOCs, 0.56 for $\mathrm{NO}_{x}$ and 0.7 for CO.

Speciation of $\mathrm{HC}$ emitted by combustion of fossil fuels was performed for each of the fuels evaluated (hydrated ethanol, gasohol and diesel). Three processes were considered: evaporative emissions occurring in the combustion chamber, together with other evaporative gas emissions from liquid fuel; emission resulting from vehicle replenishment or from fuel transfer from tanker to pump at gas stations; and exhaust emissions.
In order to calculate evaporative emissions, speciation of liquid fuel was achieved by chromatographic analysis of fuel samples collected from the major distributors in the MASP. After identification and quantification, the compounds found in gasohol and hydrated ethanol was lumped into groups according to the SAPRC99 $[23,24]$.

The HC species emitted by evaporation due to the fuel transfer process were also determined from the composition of the liquid fuels and based on the partial pressure of the HC compounds, as described by Harley et al. [23]. Speciation of $\mathrm{HC}$ emitted by vehicle exhaust was based on previous in-tunnel measurements [25] and on data reported in the works of Murgel (1990) [26] and Chuí et al. [27]. The species used to represent the organic emissions were as follows: ACET (ketone group); ALK1 (alkane group 1); ALK2 (alkane group 2); ALK3 (alkane group 3); ARO1 (aromatics group 1); ARO2 (aromatics group 2); BALD (benzaldehydelike aromatic aldehydes); BUTD (1,3-butadiene); $\mathrm{C}_{2} \mathrm{H}_{2}$ (acetylene); $\mathrm{C}_{2} \mathrm{H}_{6}$ (ethane); $\mathrm{C}_{3} \mathrm{H}_{8}$ (propane); $\mathrm{C}_{6} \mathrm{H}_{6}$ (benzene); CCHO (acetaldehyde); ETHE (ethene); ETOH (ethanol); HCHO (formaldehyde); ISOP (isoprene); MEK (methyl ethyl ketone); OLE1 (olefin group 1); OLE2 (olefin group 2); RCHO (propionaldehyde and all higher aldehydes); TOLU (toluene); and UNID (unidentified). The VOC emissions (in tons/year) used in the base-case simulation and in the scenario simulations, together with the percentage changes in the emissions of gases or group of gases in the scenarios versus the base case, are presented in Table 1.

\section{Proposed Emission Scenarios}

There is a global trend toward a reduction in vehicle emissions, and emission standards are becoming more restrictive. Therefore, it is necessary the technology improvement on new motors and the developing of gasoline reformulation to meet the new emission standards. Table $\mathbf{2}$ presents the proposals for gasohol reformulation in Brazil, together with gasoline reformulation proposals for the state of California and for the European Union.

Four scenarios were developed based on the gasoline characteristics shown in Table 2, and a fifth was developed based on reducing concentrations of the MASP species presenting the greatest ozone sensitivity, considering the fraction of VOCs in the emissions inventory used. A sixth scenario was developed to evaluate the effects that the exclusive use of ethanol would have on ozone concentrations in the MASP. The scenarios are described below:

Scenario 1. An 11.1\% reduction in the fractions of the olefins (OLE1, OLE2, BUTD and ETHE), the aromatics (ARO1, ARO2 and TOLU) and benzene $\left(\mathrm{C}_{6} \mathrm{H}_{6}\right)$ from gasohol (Tables $\mathbf{1}$ and 2) in relation to the base case according to the Brazilian National Petrol Agency proposal for 2007.

Scenario 2. A $20 \%$ reduction in the fractions of the olefins (OLE1, OLE2, BUTD and ETHE), the aromatics (ARO1, ARO2 and TOLU) and benzene $\left(\mathrm{C}_{6} \mathrm{H}_{6}\right)$ from gasohol in relation to the base 
Table 1. Emissions in the MASP Domain for the Base Case and for Scenarios 1 to 6, Together with Percentage Changes Between the Base Case (2004) and the Scenarios in Terms of the Emissions of Gases and Groups of Gases

\begin{tabular}{|c|c|c|c|c|c|c|c|c|c|c|c|c|c|}
\hline \multirow[b]{2}{*}{ Species } & \multicolumn{7}{|c|}{1000 Tons/Year } & \multicolumn{6}{|c|}{ Percentage (\%) } \\
\hline & BC & S1 & S2 & S3 & S4 & S5 & S6 & $\begin{array}{l}\text { S1- } \\
\text { BC }\end{array}$ & $\begin{array}{l}\text { S2- } \\
\text { BC }\end{array}$ & $\begin{array}{l}\text { S3- } \\
\text { BC }\end{array}$ & $\begin{array}{l}\text { S4- } \\
\text { BC }\end{array}$ & \begin{tabular}{|l|} 
S5- \\
BC
\end{tabular} & S6-BC \\
\hline $\mathrm{CO}$ & 1292.6 & 1292.6 & 1292.6 & 1292.6 & 1292.6 & 1292.6 & 2184.7 & 70.0 & 0.0 & 0.0 & 0.0 & 0.0 & +69.0 \\
\hline NOx & 60.8 & 60.8 & 60.8 & 60.8 & 60.8 & 60.8 & 45.4 & 0.0 & 0.0 & 0.0 & 0.0 & 0.0 & -25.3 \\
\hline VOCs & 302.9 & 290.6 & 280.6 & 246.4 & 271.0 & 266.5 & 279.8 & -4.1 & -7.4 & $-18.7 \mid$ & -10.5 & $\mid-12.0$ & -7.6 \\
\hline ACET & 0.5 & 0.5 & 0.5 & 0.5 & 0.5 & 0.5 & 0.0 & 0.0 & 0.0 & 0.0 & 0.0 & 0.0 & -100.0 \\
\hline ALK1 & 9.4 & 9.4 & 9.4 & 9.4 & 9.4 & 9.4 & 0.0 & 0.0 & 0.0 & 0.0 & 0.0 & 0.0 & -100.0 \\
\hline ALK2 & 36.6 & 36.6 & 36.6 & 36.6 & 36.6 & 36.6 & 0.0 & 0.0 & 0.0 & 0.0 & 0.0 & 0.0 & -100.0 \\
\hline ALK3 & 45.5 & 45.5 & 45.5 & 45.5 & 45.5 & 45.5 & 0.0 & 0.0 & 0.0 & 0.0 & 0.0 & 0.0 & -100.0 \\
\hline ARO1 & 5.8 & 5.2 & 4.6 & 4.5 & 4.5 & 5.8 & 1.0 & -11.1 & -20.0 & -22.2 & -22.2 & 0.0 & -83.4 \\
\hline ARO2 & 41.6 & 37.0 & 33.3 & 32.4 & 32.4 & 25.0 & 3.0 & -11.1 & -20.0 & -22.2 & -22.2 & $|-40.0|$ & -92.8 \\
\hline BALD & 0.1 & 0.1 & 0.1 & 0.1 & 0.1 & 0.1 & 0.0 & 0.0 & 0.0 & 0.0 & 0.0 & 0.0 & -100.0 \\
\hline BUTD & 0.0 & 0.0 & 0.0 & 0.0 & 0.0 & 0.0 & 0.0 & -11.1 & -20.0 & -86.6 & -40.0 & \begin{tabular}{|l|} 
\\
\end{tabular} & -100.0 \\
\hline $\mathrm{C} 2 \mathrm{H} 2$ & 13.4 & 13.4 & 13.4 & 13.4 & 13.4 & 13.4 & 0.0 & 0.0 & 0.0 & 0.0 & 0.0 & 0.0 & -100.0 \\
\hline $\mathrm{C} 2 \mathrm{H} 6$ & 9.9 & 9.9 & 9.9 & 9.9 & 9.9 & 9.9 & 0.0 & 0.0 & 0.0 & 0.0 & 0.0 & 0.0 & -100.0 \\
\hline $\mathrm{C} 3 \mathrm{H} 8$ & 8.1 & 8.1 & 8.1 & 8.1 & 8.1 & 8.1 & 0.0 & 0.0 & 0.0 & 0.0 & 0.0 & 0.0 & -100.0 \\
\hline C6H6 & 6.5 & 5.8 & 5.2 & 4.6 & 6.5 & 6.5 & 0.0 & -11.1 & -20.0 & -30.0 & 0.0 & 0.0 & -100.0 \\
\hline $\mathrm{CCHO}$ & 1.1 & 1.1 & 1.1 & 1.1 & 1.1 & 1.1 & 26.4 & 0.0 & 0.0 & 0.0 & 0.0 & 0.0 & +2361.9 \\
\hline ETHE & 12.4 & 11.0 & 9.9 & 1.7 & 7.4 & 7.4 & 6.2 & -11.1 & -20.0 & -86.6 & -40.0 & $|-40.0|$ & -49.7 \\
\hline ETOH & 64.0 & 64.0 & 64.0 & 64.0 & 64.0 & 64.0 & 237.4 & 0.0 & 0.0 & 0.0 & 0.0 & 0.0 & +270.7 \\
\hline $\mathrm{HCHO}$ & 0.8 & 0.8 & 0.8 & 0.8 & 0.8 & 0.5 & 4.8 & 0.0 & 0.0 & 0.0 & 0.0 & $|-40.0|$ & +507.6 \\
\hline ISOP & 0.5 & 0.5 & 0.5 & 0.5 & 0.5 & 0.5 & 0.0 & 0.0 & 0.0 & 0.0 & 0.0 & 0.0 & -100.0 \\
\hline MEK & 0.2 & 0.2 & 0.2 & 0.2 & 0.2 & 0.2 & 0.0 & 0.0 & 0.0 & 0.0 & 0.0 & 0.0 & -100.0 \\
\hline OLE1 & 14.7 & 13.1 & 11.8 & 2.0 & 8.8 & 8.8 & 0.2 & -11.1 & -20.0 & -86.6 & -40.0 & $|-40.0|$ & -98.9 \\
\hline OLE2 & 21.5 & 19.1 & 17.2 & 2.9 & 12.9 & 12.9 & 0.2 & -11.1 & -20.0 & -86.6 & -40.0 & $\mid-40.0$ & -99.3 \\
\hline $\mathrm{RCHO}$ & 0.5 & 0.5 & 0.5 & 0.5 & 0.5 & 0.5 & 0.0 & 0.0 & 0.0 & 0.0 & 0.0 & 0.0 & -100.0 \\
\hline TOLU & 8.8 & 7.9 & 7.1 & 6.9 & 6.9 & 8.8 & 0.0 & -11.1 & -20.0 & -22.2 & -22.2 & \begin{tabular}{|l|} 
\\
\end{tabular} & -100.0 \\
\hline \multirow[t]{2}{*}{ UNID } & 1.0 & 1.0 & 1.0 & 1.0 & 1.0 & 1.0 & 0.7 & 0.0 & 0.0 & 0.0 & 0.0 & 0.0 & -32.0 \\
\hline & \multicolumn{13}{|c|}{ Total emitted from gasohol, ethanol and diesel in the MASP (1000 tons/year) } \\
\hline $\mathrm{CO}$ & 1706.1 & 1706.1 & 1706.1 & 1706.1 & 1706.1 & 1706.1 & 2598.2 & 0.0 & 0.0 & 0.0 & 0.0 & 0.0 & +52.3 \\
\hline NOx & 356.5 & 356.5 & 356.5 & 356.5 & 356.5 & 356.5 & 341.1 & 0.0 & 0.0 & 0.0 & 0.0 & 0.0 & -4.3 \\
\hline VOCs & 383.7 & 371.3 & 361.4 & 327.2 & 351.8 & 347.3 & 342.6 & -3.2 & -5.8 & -14.7 & -8.3 & -9.5 & -10.7 \\
\hline $\mathrm{SO} 2$ & 20.8 & 20.8 & 20.8 & 20.8 & 20.8 & 20.8 & 20.8 & 0.0 & 0.0 & 0.0 & 0.0 & 0.0 & 0.0 \\
\hline
\end{tabular}

${ }^{\mathrm{a}}$ Without considering the adjusted factors used equally in all simulations.

BC: base case; S: scenario; CO: carbon monoxide; $\mathrm{NO}_{\mathrm{x}}$ : nitrogen oxides; VOCs: volatile organic compounds; ACET: ketone group; ALK1: alkane group 1; ALK2: alkane group 2; ALK3: alkane group 3; ARO1: aromatics group 1; ARO2: aromatics group 2; $B A L D$ : benzaldehyde-like aromatic aldehydes; $B$ TD: 1,3 -butadiene; $\mathrm{C}_{2} \mathrm{H}_{2}$ : acetylene; $\mathrm{C}_{2} \mathrm{H}_{6}$ : ethane; $\mathrm{C}_{3} \mathrm{H}_{8}$ : propane; $\mathrm{C}_{6} \mathrm{H}_{6}$ : benzene; CCHO: acetaldehyde; ETHE: ethene; ETOH: ethanol; HCHO: formaldehyde; ISOP: isoprene; MEK: methyl ethyl ketone; OLE1: olefin group 1; OLE2: olefin group 2; RCHO: propionaldehyde and all higher aldehydes; TOLU: toluene; UNID: unidentified; $\mathrm{SO}_{2}$ : sulfur dioxide.

case. For 2009, the Brazilian National Petrol Agency did not specify the level of reduction, and a $20 \%$ reduction is proposed (Tables 1 and 2).
Scenario 3. In this scenario, it was supposed that Brazilian gasohol would have the same volume fractions of olefins, aromatics and benzene that California gasoline has, although the quantity of oxy- 
Table 2. Future Characteristics of Brazilian Gasohol, as Proposed by Brazilian National Petrol Agency, Together with those of California Gasoline and European Union Gasoline

\begin{tabular}{|l|c|c|c|c|}
\hline \multicolumn{1}{|c|}{$\begin{array}{c}\text { Basic Characteristics of } \\
\text { Gasoline }\end{array}$} & $\begin{array}{c}\text { Sulfur } \\
\mathbf{( \% )}\end{array}$ & $\begin{array}{c}\text { Aromatics } \\
\mathbf{( \% )}\end{array}$ & $\begin{array}{c}\text { Olefins } \\
\mathbf{( \% )}\end{array}$ & $\begin{array}{c}\text { Benzene } \\
\mathbf{( \% )}\end{array}$ \\
\hline \hline Current specifications & 0.1 & 45 & 30 & 1.0 \\
\hline Proposal for 01/01/2007 & 0.04 & 40 & 25 & - \\
\hline Proposal for 01/01/2009 & 0.005 & - & - & - \\
\hline $\begin{array}{l}\text { California (USA) (Year of } \\
\text { implementation) }\end{array}$ & $\begin{array}{c}0.0015 \\
(2002)\end{array}$ & $35(2003)$ & $\begin{array}{c}4 \\
(2005)\end{array}$ & $\begin{array}{c}0.7 \\
(2005)\end{array}$ \\
\hline $\begin{array}{l}\text { European Union (Year of im- } \\
\text { plementation) }\end{array}$ & $\begin{array}{c}0.005 \\
(2005)\end{array}$ & $35(2005)$ & $\begin{array}{c}18 \\
(2005)\end{array}$ & $1(2005)$ \\
\hline
\end{tabular}

Source: Petrobrás Technical Bulletin (Dauzacher and Palombo 2003) [28].

genates would differ, since Brazilian gasoline contains $22-25 \%$ ethanol. As shown in Tables $\mathbf{1}$ and $\mathbf{2}$, the assumptions were as follows: olefins would be reduced from $30 \%$ to $4 \%$ (a reduction of $86.6 \%$ ); aromatics would be reduced from $45 \%$ to $35 \%$ (a reduction of $22.2 \%$ ); and benzene would be reduced from $1 \%$ to $0.7 \%$ (a reduction of $30 \%$ ).

Scenario 4. In this scenario, it was supposed that Brazilian gasohol would have the same volume fractions of olefins, aromatics and benzene that European Union gasoline has, although, again, the quantity of oxygenates would differ. As can be seen in Tables $\mathbf{1}$ and $\mathbf{2}$, the assumptions were as follows: olefins would be reduced from $30 \%$ to $18 \%$ (a reduction of $40 \%$ ); aromatics would be reduced from $45 \%$ to $35 \%$ (a reduction of $22.2 \%$ ); and the benzene fraction would be unchanged.

Scenario 5. This scenario involved a $40 \%$ reduction in the volume fractions of the five MASP species that presented the greatest ozone sensitivity, as identified through a sensitivity analysis performed for the MASP. In the first five scenarios, the fractions of reduction were the same for all of the emissions processes considered: evaporative emissions, emissions resulting from vehicle replenishment and exhaust emissions.

Scenario 6. In this scenario, it was supposed that entire light-duty fleet would run on hydrated ethanol. In the MASP, light-duty vehicles make up $94.3 \%$ of the fleet. Of this sub-fleet, $14.5 \%$ run on hydrated ethanol, $69.5 \%$ run on gasohol, $9.3 \%$ are motorcycles that burn gasohol, and $1 \%$ are flex-fuel vehicles that can run on gasohol or hydrated ethanol (data from 2004) [6]. In this scenario it was assumed that the flexfuel vehicles would burn only hydrated ethanol, and therefore $15.5 \%$ of the light-duty fleet would be running on hydrated ethanol.
According to tests performed in 2005 by CETESB [1] in order to meet the PROCONVE requirements, the average emission factors for new vehicles running on gasohol were $3.83 \mathrm{~g} \mathrm{l}^{-1}$ for $\mathrm{CO}, 1.13 \mathrm{~g} \mathrm{l}^{-1}$ for $\mathrm{HC}$ and $1.02 \mathrm{~g} \mathrm{l}^{-1}$ for $\mathrm{NO}_{x}$, whereas those for new vehicles running on pure ethanol were $7.04 \mathrm{~g} \mathrm{l}^{1}$ for $\mathrm{CO}, 1.46 \mathrm{~g} \mathrm{l}^{-1}$ for $\mathrm{HC}$ and $0.69 \mathrm{~g} \mathrm{l}^{-1}$ for $\mathrm{NO}_{x}$. Therefore, in this scenario, the percentage difference between each emission factor for gasohol and ethanol was used to estimate, in terms of exhaust emissions, the changes from gasohol (in the base case) to ethanol: those of $\mathrm{CO}$ increased by $83 \%$; those of $\mathrm{HC}$ increased by $29.2 \%$; and those of $\mathrm{NO}_{x}$ decreased by $32.3 \%$. For emissions from vapor and liquid fuel, a factor of 6.08 was used to calculate the increase in emissions from all light-duty vehicles running on hydrated ethanol only. The differences between the hydrated ethanol scenario and the base case, in terms of emissions, are presented in Table $\mathbf{1}$.

\section{RESULTS}

\section{Model Evaluation}

Simulations were performed for the base case from September 6 to September 10 coinciding with the period of ozone measurements. The comparison between predicted ozone concentrations and those observed at two groups of air quality station located in the MASP is presented in Fig. (2). The grouping of the stations was based on the results of a cluster analysis, using Euclidian distance and ward clustering, of all the air quality stations in the MASP. Group 1 was composed of the following stations: Moóca $\left(23.55^{\circ} \mathrm{S}\right.$; $\left.46.64^{\circ} \mathrm{W}\right)$; Ibirapuera $\left(23.58^{\circ} \mathrm{S} ; 46.66^{\circ} \mathrm{W}\right)$; São Caetano do Sul $\left(23.62^{\circ} \mathrm{S} ; 46.55^{\circ} \mathrm{W}\right)$; and Pinheiros $\left(23.56^{\circ} \mathrm{S} ; 46.70^{\circ} \mathrm{W}\right)$. Group 2 was composed of only two stations: Diadema $\left(23.67^{\circ} \mathrm{S} ; 46.61^{\circ} \mathrm{W}\right)$ and Santo Amaro $\left(23.65^{\circ} \mathrm{S} ; 46.71^{\circ} \mathrm{W}\right)$. The group 1 stations were primarily affected by vehicle emissions, whereas the group 2 stations were affected by a combination of vehicle and industrial emissions. The stations of group 2 are located in the southeastern part of the MASP and are early affected by sea breeze.

The ozone concentrations predicted by the model were consistent with the observed values. The correlation coefficients, between hourly simulated concentrations and hourly observed concentrations, were satisfactory $(0.86$ and 0.77 for groups 1 and 2, respectively), indicating that, for both 
groups, the model is capable of representing the ozone behavior, as well as the variations in concentrations throughout the day. However, at night the representative values were lower.

The CIT model was applied for two other periods and the results for base case simulations as well the sensitivity analyses are presented in Martins and Andrade [29].

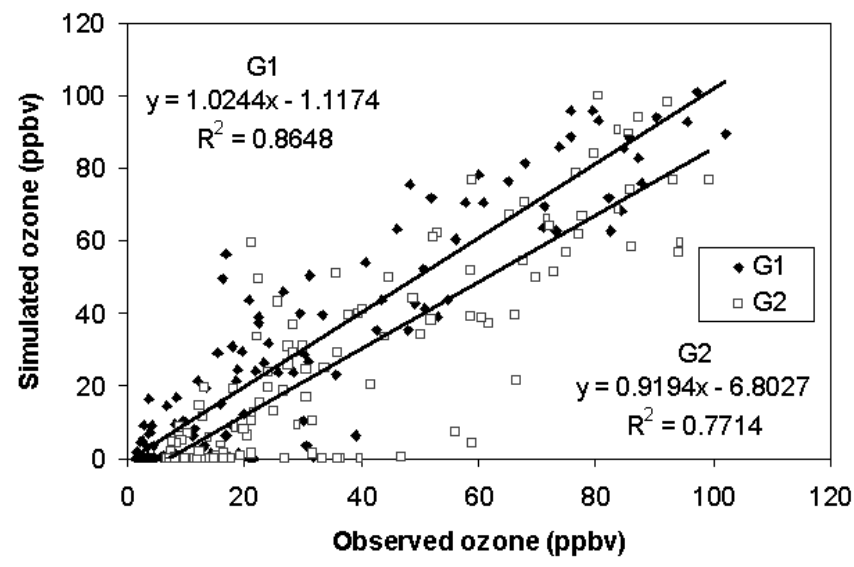

Fig. (2). Comparison of ozone concentrations observed at group 1 (G1) and group 2 (G2) air quality stations, together with simulated ozone concentrations, for the period from September 6 to September 10 of 2004 .

\section{Ozone Sensitivity Analysis}

The sensitivity of ozone concentrations to twenty-four species were calculated through the finite different approximation of the first-order:

$$
S^{(1)} \approx \frac{C_{+\Delta E j}-C_{-\Delta E j}}{2 \Delta E_{j}}
$$

where $C_{+\Delta E j}$ is the ozone concentration of the perturbation case $(+15 \%)$, and $C_{-\triangle E j}$ is the ozone concentration of the perturbation case $(-15 \%)$. The fractional perturbation in the parameter is denoted by $\Delta E_{j}=\left(E_{j}-1\right)$ [30].

Fig. (3) shows the hourly averages of the maximum ozone sensitivities calculated for twenty-four species throughout the domain and for the entire period. The sensitivity calculated is for the whole domain, taking in account the vehicle emission rate of individual VOCs used in the emissions inventory. The ozone sensitivity to VOCs was found to be much higher than the ozone sensitivity to $\mathrm{NO}_{x}$. The sensitivity profile at group 1 and group 2 stations were comparable, with maximum sensitivity occurring near the ozone peak, although varying in intensity. This behavior is associated with the $\mathrm{VOC} / \mathrm{NO}_{x}$ ratios and the location of the emissions within the region studied.

The species ARO2, OLE1, OLE2, ETHE and HCHO were the five that had the most influence on ozone formation in the MASP. As previously stated, scenario 5 involved reductions in the emissions of these five species. It is of note that $\mathrm{CCHO}$, which is emitted mainly from the combustion of ethanol, also proved important for ozone formation in the MASP.

\section{Impact of Proposed Emission Scenarios on Air Quality}

The time series of simulated ozone concentrations for the six scenarios and for the base case at the surface air quality stations in both groups are presented in Fig. $(\mathbf{4 a}, \mathbf{b})$.

The simulations showed a reduction in the average ozone concentrations and ozone peak for the entire period for all six scenarios in relation to the base case. The ozone response to emission control was observed from the first day evaluated, although the maximum ozone response was found to occur on the third day during the event studied. This was probably due to the meteorological conditions on that day, which presented, for example the lowest wind velocity of the period. However, Vautard et al. (AE 2005) [31] found similar results during the heat wave that occurred in northwestern

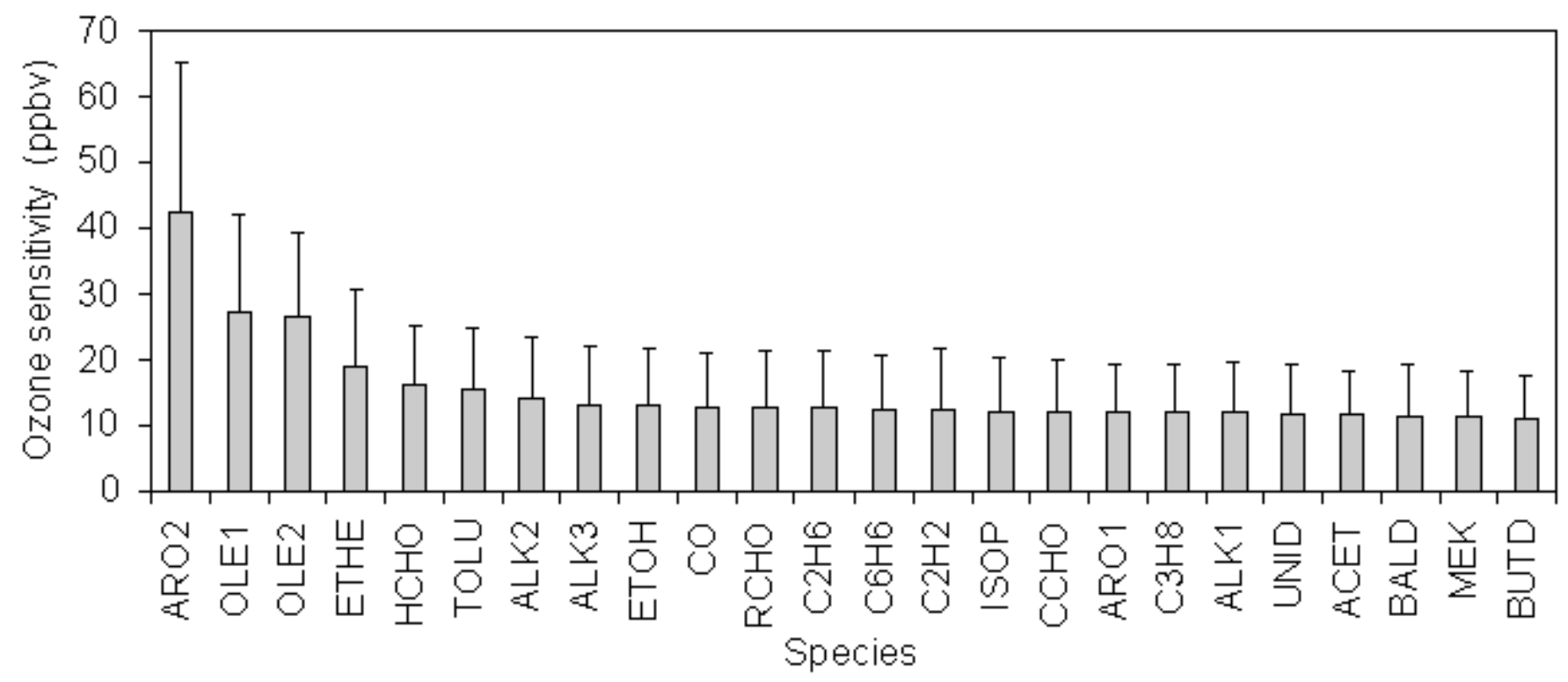

Fig. (3). Ozone sensitivity throughout the surface domain from September 6 to September 10 of 2004. 

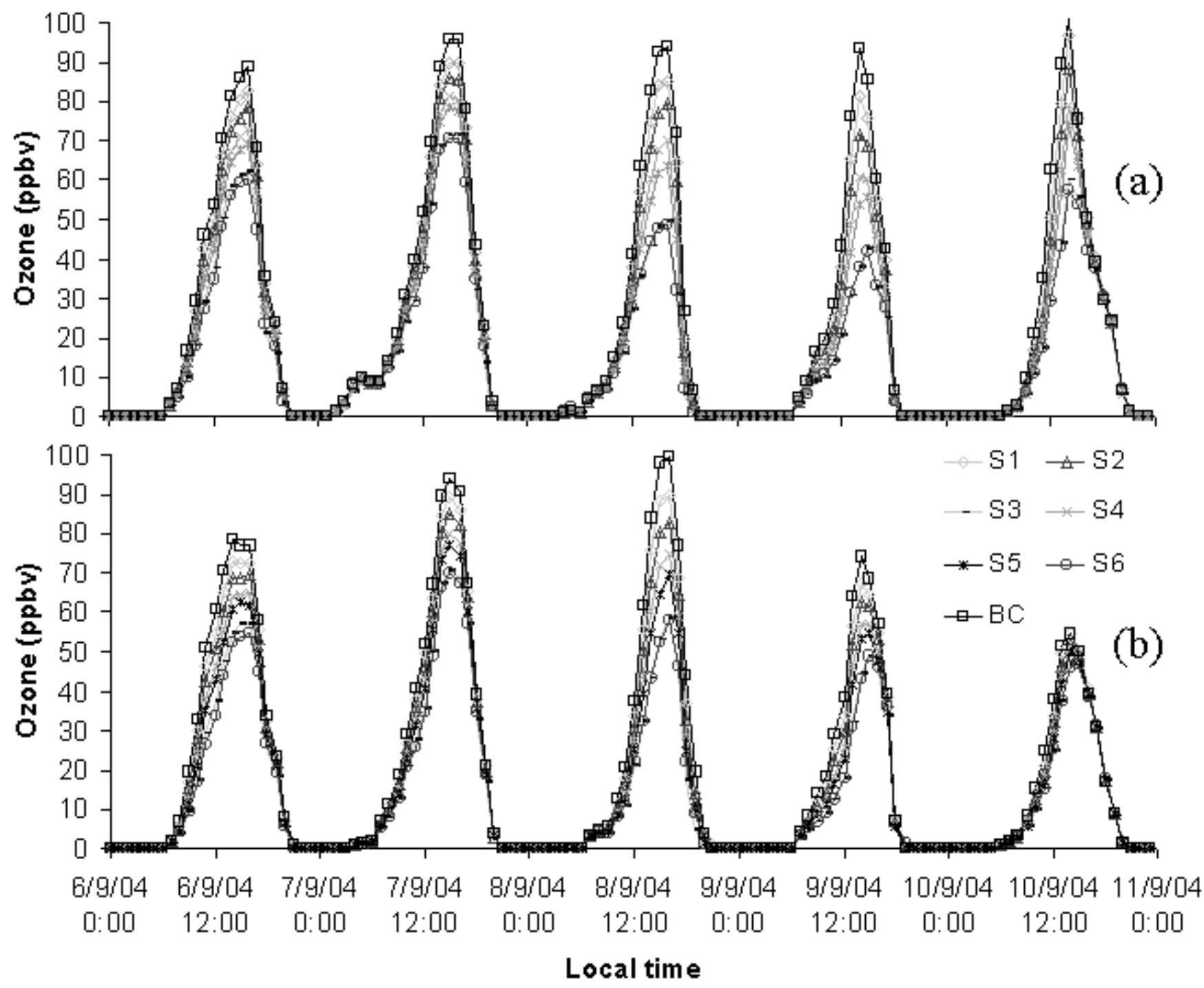

Fig. (4). Ozone concentrations simulated for five different scenarios at group 1 (a) and group 2 (b) air quality stations.

Europe in August of 2003. The authors determined that the effects of the emission reduction on ozone can be seen from the first day of the reduction, although the response does not reach full efficiency until 3 days later.

The greatest reductions were observed on days 8 and 9 at the group 1 stations, and the reductions in the ozone peaks were significantly greater at the group 1 stations than at the group 2 stations. This is attributable to the fact that ozone sensitivity to VOC emissions was higher at group 1 stations (Fig. 4a) than at group 2 stations (Fig. 4b). In scenarios 3 and 5, the ozone concentrations were reduced to below the national air quality standard at the group 1 and group 2 stations, although not throughout the domain. In addition, scenario 3 resulted in a $43 \%$ reduction in the number of grid points with ozone concentrations above the air quality standard $(\cong 82 \mathrm{ppbv}$ for 1 hour). Among the scenarios involving the reformulation of gasohol, scenario 3 also proved to be the most effective at reducing ozone concentrations. It is noteworthy that, in scenario 3 , eight species were reduced, whereas only five were reduced in scenario 5. Therefore, reducing emissions of species to which ozone is more sensitive can result in more effi- cient ozone control. Table 3 summarizes the percentage reductions in ozone concentrations at the group 1 and group 2 stations in relation to the base case for all six scenarios.

Scenario 6, in which the principal fuel combusted is hydrated ethanol, resulted in the greatest decrease in ozone concentrations in MASP, even when compared with scenario 3. However, the difference between the two scenarios was small and shifted between positive and negative values depending on the region. The combustion of ethanol resulted in lower emissions of the species with high ozone formation potential, such as the olefins and aromatics, than did that of gasohol. Nevertheless, the emission of aldehyde compounds (mainly $\mathrm{CCHO}$ ), increased considerably in scenario 6 , in which $73.1 \%$ of the VOCs emitted in the exhaust of vehicles running on hydrated ethanol consisted of unburned ethanol, the oxidation of which is a major source of CCHO. In scenario 6, the number of grid points presenting ozone concentrations above the air quality standard was reduced by $42 \%$ in comparison with the base case. This is comparable to the reduction seen in scenario 3. 
Table 3. Ozone Concentrations at Group 1 and Group 2 Air Quality Stations: Average Reductions in Ozone Concentrations and Reductions in the Ozone Peak for the Six Scenarios in Relation to the Base Case

\begin{tabular}{|c|c|c|c|c|c|c|c|c|c|c|c|c|c|}
\hline \multirow{3}{*}{ Date } & & \multicolumn{12}{|c|}{$\mathrm{O}_{3}$ Reduction in Relation to the $\mathrm{BC}(\%)$} \\
\hline & & \multicolumn{2}{|c|}{ S1 } & \multicolumn{2}{|c|}{ S2 } & \multicolumn{2}{|c|}{ S3 } & \multicolumn{2}{|c|}{ S4 } & \multicolumn{2}{|c|}{ S5 } & \multicolumn{2}{|c|}{ S6 } \\
\hline & & G1 & G2 & $\begin{array}{c}G \\
1\end{array}$ & $\begin{array}{l}\text { G } \\
\mathbf{2}\end{array}$ & $\begin{array}{c}G \\
1\end{array}$ & $\begin{array}{l}\text { G } \\
2\end{array}$ & $\begin{array}{l}G \\
1\end{array}$ & $\begin{array}{l}\text { G } \\
2\end{array}$ & $\begin{array}{l}G \\
1\end{array}$ & $\begin{array}{l}\mathbf{G} \\
2\end{array}$ & $\begin{array}{c}G \\
1\end{array}$ & $\begin{array}{l}G \\
2\end{array}$ \\
\hline \multirow{4}{*}{ 06/09 } & Aver- & 6.5 & 7.0 & $\begin{array}{r}11 \\
5\end{array}$ & 12 & 31 & 31 & 17 & 18 & 21 & 23 & 32 & $\begin{array}{c}3 \\
3 .\end{array}$ \\
\hline & & & & & & & & & & & & & \\
\hline & Peak of & 6.8 & 7.0 & 11 & 11 & $\begin{array}{r}29 \\
0\end{array}$ & 27 & $\begin{array}{r}17 \\
5\end{array}$ & 17 & 22 & 20 & 32 & $\begin{array}{l}2 \\
9 .\end{array}$ \\
\hline & & & & & & & & & & & & & \\
\hline \multirow{4}{*}{ 07/09 } & Aver- & 53 & 49 & 8. & 9. & 24 & 24 & 14 & 14 & 16 & 17 & 22 & $\begin{array}{l}2 \\
4\end{array}$ \\
\hline & age & J. & 4.9 & 9 & 2 & .5 & .4 & .1 & .2 & .7 & .2 & .8 & \\
\hline & Peak of & 63 & 53 & 10 & 9. & 25 & 25 & 15 & 14 & 18 & 18 & 26 & $\begin{array}{l}2 \\
5\end{array}$ \\
\hline & $\mathrm{O}_{3}$ & 6.3 & 5.3 & .2 & 6 & .1 & .0 & .1 & .9 & .3 & .1 & .1 & $\begin{array}{l}5 . \\
5\end{array}$ \\
\hline \multirow{4}{*}{ 08/09 } & Ave & 10. & 11. & 17 & 18 & 46 & 46 & 27 & 27 & 33 & 34 & 45 & 4 \\
\hline & age & 2 & 0 & .4 & .1 & .6 & .3 & .0 & .9 & .4 & .0 & .2 & $\begin{array}{l}4 . \\
4\end{array}$ \\
\hline & Peak of & & & 15 & 16 & 47 & 41 & 25 & 24 & 32 & 30 & 48 & 4 \\
\hline & $\mathrm{O}_{3}$ & 9.6 & 9.3 & .7 & .6 & .3 & .2 & .3 & .6 & .2 & .2 & .1 & 7 \\
\hline \multirow{4}{*}{ 09/09 } & Ave & 11. & & 20 & 14 & 51 & 37 & 30 & 22 & 37 & 27 & 50 & 3 \\
\hline & age & 1 & 8.3 & .3 & .5 & .5 & .4 & .6 & .2 & .0 & .5 & .1 & $\begin{array}{l}6 . \\
5\end{array}$ \\
\hline & Peak of & 12. & & 23 & 15 & 54 & 33 & 34 & 23 & 40 & 26 & 55 & 3 \\
\hline & $\mathrm{O}_{3}$ & 6 & 9.3 & .6 & .5 & .4 & .8 & .9 & .0 & .2 & .4 & .0 & $\begin{array}{l}3 . \\
8\end{array}$ \\
\hline \multirow{4}{*}{$10 / 09$} & Aver- & & & 12 & 6. & 33 & 16 & 19 & 9. & 24 & 11 & 33 & 1 \\
\hline & age & 1.0 & 3.2 & .6 & 2 & .5 & .3 & .9 & 2 & .3 & .8 & .5 & $\begin{array}{l}5 . \\
5\end{array}$ \\
\hline & Peak of & & & 12 & 2. & 40 & 12 & 21 & 6. & 26 & 8. & 42 & \\
\hline & $\mathrm{O}_{3}$ & 4.2 & 0 & .2 & 8 & .4 & .8 & .6 & 4 & .8 & 3 & .7 & $\begin{array}{l}3 . \\
8\end{array}$ \\
\hline \multirow{4}{*}{$\begin{array}{l}\text { Whole } \\
\text { Period }\end{array}$} & Aver- & 78 & & 13 & 12 & 36 & 31 & 21 & 19 & 25 & 23 & 35 & 3 \\
\hline & age & 1.0 & 1.1 & .7 & .4 & .3 & .9 & .1 & .0 & .8 & .3 & .8 & 9 \\
\hline & Peak of & 79 & 63 & 14 & 11 & 39 & 28 & 22 & 17 & 27 & 20 & 40 & 2 \\
\hline & $\mathrm{O}_{3}$ & 1.9 & 0.3 & .6 & .2 & .4 & .0 & .9 & .2 & .9 & .6 & .8 & $\begin{array}{l}\text {. } \\
9\end{array}$ \\
\hline
\end{tabular}

$\mathrm{O}_{3}$ : ozone; $\mathrm{BC}$ : base case; $\mathrm{S}$ : scenario; G: group.

The simulated peak ozone concentrations throughout the domain for scenarios 3 and 6 on September 8 of 2004 are presented in Fig. (5a,b). Fig. (5) also illustrates the regions and magnitudes of reduction in the ozone concentrations in relation to the base case. A significant reduction in average as well as peak ozone concentrations was observed at all of the air quality stations. However, the plume ozone concentrations presented no reduction and were not sensitive to the reduced emissions of olefins, aromatics and benzene proposed in scenario 3 . Even in scenario 6 , the plume ozone concentrations did not decrease. The effect of reducing the emissions of olefins and aromatics was a decrease in the total reactivity of VOC emissions in the MASP, although the contributions of other VOC species did not change. Therefore, the emissions of species less reactive for ozone formation increased far from the VOC source and therefore had no effect on the plume ozone concentrations. Outside the MASP, ozone proved to be more sensitive to the emissions of VOCs and $\mathrm{NO}_{\mathrm{x}}$.

\section{DISCUSSION AND CONCLUSIONS}

Jacobson (ES\&T 2007) [12] recently compared the health effects of gasoline use to those of ethanol use. He developed future scenarios for the United States: one in which the fleet would run on gasoline and another in which it would run on E85 (85\% ethanol fuel, $15 \%$ gasoline). The results indicated that the E85 scenario would increase ozone concentrations and have ill effects on the health of the population. These results are different from those found in the present study. This discrepancy might be explained by the fact that the fraction of olefins and aromatic compounds found in Brazilian gasohol differ from those found in gasoline sold in the United States (Table 2). In addition, approximately $34 \%$ of 
the light-duty fleet in Brazil already runs on pure ethanol.Therefore, in our scenario 6 , there was only a 2.9 -times increase in the quantity of ethanol combusted, compared with a 17-times increase in the Jacobson study. Furthermore, other minor factors, such as differences in the meteorological conditions, the treatment of the physical-chemical processes in the models and the model resolution, might account for the differences between the two studies. It should be also taken into consideration that, in the present study, a base case scenario in which the fleet is running on a gasolineethanol blend (22\% ethanol) was compared to a scenario in which the entire fleet would be running on pure ethanol,
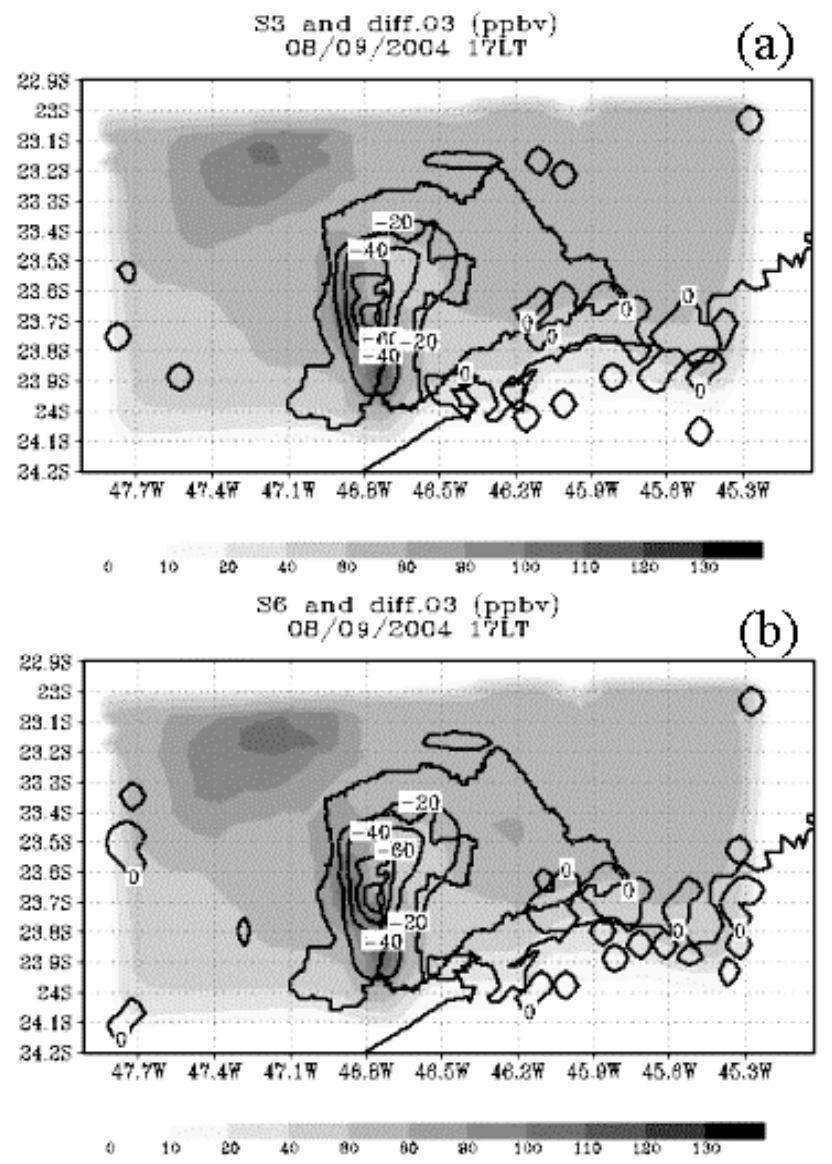

Fig. (5). Ozone concentration peaks simulated for the entire domain on September 8 of 2004: (a) for scenario 3 (S3); and (b) for scenario 6 (S6). The contours illustrate the regions and the intensity of the reduction in ozone concentrations in relation to the base case.

often referred to as E100. Therefore, it is difficult to draw comparisons between our study and that of Jacobson, in

which the effects on cancer and mortality were examined by comparing a base case scenario and a future scenario respectively involving the use of pure gasoline and E85.

In emission scenarios 1 and 2, which simulated the conditions of Brazilian gasohol reformulations proposed for 2007 and 2009, respectively, there was a slight reduction in the average and peak ozone concentrations. According to the modeled data, the average reductions at the group 1 stations in scenarios 1 and 2 were, respectively, $7.8 \%$ and $13.7 \%$ for the domain-wide ozone concentrations and $7.9 \%$ and $14.6 \%$ for the ozone peak. Based on the simulations, these reductions would not be sufficient to bring the ozone concentrations to below the air quality standard in either scenario (scenario 1 or scenario 2) during the event studied. It should be noted that, although policies regarding fuel reformulation and alternative energy sources are important for improving air quality in urban areas, policies designed to improve the public transportation system and limit vehicle emissions, as well as to monitor and manage the flow of traffic, are of equal importance.

\section{ACKNOWLEDGMENTS}

This study received financial support in the form of a grant from the Fundação de Amparo à Pesquisa do Estado de São Paulo (FAPESP, Foundation for the Support of Research in the State of São Paulo; grant No. 02/09060-1). Also, with the aid a grant (SAEMC project) from the Inter-American Institute for Global Change Research (IAI) CRN II 2017 which is supported by the US National Science Foundation (Grant GEO-0452325). We would like to thank the São Paulo State Companhia de Tecnologia de Saneamento Ambiental (CETESB, Environmental Regulation Agency) for providing the air quality data. The authors are also grateful to Jefferson D. Boyles for editing the text.

\section{REFERENCES}

[1] CETESB. Relatório de qualidade do ar no Estado de São Paulo 2005 [in portuguese]. Série Relatórios/Secretaria do Estado do Meio Ambiente, São Paulo, 2006. 140p. Available from: http://www. cetesb.sp.gov.br.

[2] Szwarcfiter L, Mendes FE, La Rovere EL. Enhancing the effects of the Brazilian program to reduce atmospheric pollutant emissions from vehicles. Transport Res D-Tr E 2005; 10: 153-60.

[3] Sánchez-Ccoyllo OR, Martins LD, Ynoue RY, Andrade MF. The impact on tropospheric ozone formation on the implementation of a program for mobile emissions control: a case study in São Paulo, Brazil. Environ Fluid Mech 2007; 7: 95-119.

[4] CETESB, 1996. Comportamento Sazonal da Poluição do Ar em São Paulo - Análise de 14 anos de Dados da RMSP e Cubatão 1981 a 1994. Available from: http://www.cetesb.sp.gov.br.

[5] Muramoto CA, Lopes CFF, Lacava CIV. Study of Tropospheric Ozone in São Paulo Metropolitan Region. A\&WMA's 96th Annual Conference \& Exhibition "Energy, Economic and Global Challenges, San Diego/EUA, 2003.

[6] CETESB, 2005. Relatório de qualidade do ar no Estado de São Paulo 2004 [in portuguese] Série Relatórios/Secretaria do Estado do Meio Ambiente, São Paulo, 137p. Available from: http://www.cetesb.sp. gov.br.

[7] Braga AL, Saldiva PH, Pereira LA, et al. Health effects of air pollution exposure on children and adolescents in São Paulo, Brazil. Pediatr Pulmonol 2001; 31: 106-113.

[8] Martins LC, Latorre MdoR, Saldiva PH, Braga AL. Air pollution and emergency room visits due to chronic lower respiratory diseases in the elderly: an ecological time-series study in São Paulo, Brazil. J Occup Environ Med 2002; 44: 622-7.

[9] Andrade MF, Sánchez-Ccoyllo OR, Miranda RM. Air Pollution Evaluation Based on Energy and Emissions Inventory Reference and Alternative Scenarios (2000-2020). Integrated Environmental Strategies Project for Metropolitan Area of São Paulo (MASP), Brazil, 2004.

[10] Hsieh W, Chen R, Wu T, Lin T. Engine performance and pollutant emission of an SI engine using ethanol-gasoline blended fuels. Atmos Environ 2002; 36: 403-10. 
[11] Niven RK. Ethanol in gasoline: environmental impacts and sustainability review article. Renew Sust Energ Rev 2005; 9: 535-55.

[12] Jacobson MZ. Effects of ethanol (E85) versus gasoline vehicles on cancer and mortality in the United States. Environ Sci Technol 2007; 41: 3788 .

[13] McRae GJ, Goodin WR, Seinfeld JH. Mathematical modeling of photochemical air pollution environmental quality laboratory report number 18, 1983. California Institute of Technology, Pasadena California, 91125 .

[14] Russell AG, McCue KF, Cass GR. Mathematical modeling of the formation of nitrogen-containing air pollutants. 1. Evaluation of an eulerian photochemical model. Environ Sci Technol 1988; 22(3): 263-71.

[15] McRae GJ, Russell AG, Harley RA. CIT photochemical airshed model data preparation manual, Carnegie Mellon University, Pittsburgh, PA and California 143 Institute of Technology, Pasadena, CA. Final report to the coordinating research council under contract SCAQS-8, 1992.

[16] Carter WPL. Documentation of the saprc-99 chemical mechanism for VOC reactivity assessment volume 1 of 2 documentation text final report to california air resources board. Air pollution research center and college of engineering center for environmental research and technology, University of California, Riverside, 2000 (Contract 92329 and Contract 95-308 9252100-AP-RT17-001-FR). Available from: http://helium.ucr.edu/ carter/reactdat.htm

[17] Peterson JT. Calculated actinic fluxes $(290-700 \mathrm{~nm})$ for air pollution photochemistry applications US environmental protection agency. 1976, Research triangle parck, NC, EPA-600/4-76-025 pp 63.

[18] Harley RA, Russell AG, McRae GJ, Cass GR, Seinfeld JH. Photochemical modeling of the Southern California air quality study. Environ Sci Technol 1993; 27: 378-388.

[19] Freitas ED, Rozoff C, Cotton WR, Silva Dias PL. Interactions of urban heat island and sea breeze circulations during winter over the Metropolitan Area of São Paulo - Brazil. Bound-Lay Meteorol 2007; 122: 43-65.

[20] Goodin W, McRae G, Seinfeld JA. Comparison of interpolation methods for sparse data: application to wind and concentration fields. J Appl Meteorol 1979;18(6): 761-771.

[21] Andrade MF, Ynoue RY, Harley R, Miguel AH. Air quality model simulating photochemical formation of pollutants: the São Paulo Metropolitan Area, Brazil. Int J Environ Pollut 2004; 22: 460-475.
[22] Vivanco MG, Andrade MF. Validation of the emission inventory in the Sao Paulo Metropolitan Area of Brazil, based on ambient concentrations ratios of $\mathrm{CO}, \mathrm{NMOG}$ and $\mathrm{NO}_{\mathrm{x}}$ and on a photochemical model. Atmos Environ 2006; 40: 1189-1198.

[23] Harley RA, Couter-Burke SC, Yeung TS. Relating liquid fuel and headscape vapor composition for california reformulated gasoline samples containing ethanol. Environ Sci Technol 2000; 34: 40884094.

[24] Ynoue RY. Dissertation. Modelagem numérica da formação, crescimento e transporte das partículas inorgânicas constituintes do aerossol urbano na Região Metropolitana de São Paulo [in portuguese]. Institute of Astronomy, Geophysics and Atmospheric Sciences, University of São Paulo, 2004.

[25] Martins LD, Andrade MF, Freitas ED, et al. Emission factors for gaspowered vehicles traveling through road tunnels in São Paulo City, Brazil. Environ Sci Technol 2006; 40: 6722-9.

[26] Murgel EM. Veículos Automotores: o proálcool e a qualidade do ar. Confederação Nacional da Indústria, Rio de Janeiro, 1990.

[27] Chuí Gk, Anderson RD, Baker RE, Pinto FB. Brazilian vehicle calibration for ethanol fuels. In Proceedings of the Third International Symposium on Alcohol Fuels Technology, 1975.

[28] Dauzacher ER, Palombo F. Impacto das futuras especificações na formulação da gasolina brasileira. Boletin Técnico da Petrobrás, Rio de Janeiro, 2003, 46 (3/4) 256-269.

[29] Martins LD, Andrade MF. Ozone formation potentials of volatile organic compounds and ozone sensitivity to their emission in the megacity of São Paulo, Brazil. Water, Air, \& Soil Pollution. (For Publication).

[30] Cohan DS, Hakami A, Hu Y, Russel AG. Nonlinear Response of Ozone to Emissions: Source Apportionment and Sensitivity Analysis. Environ Sci Technol 2005; 39: 6739-6748.

[31] Vautard R, Honoré C, Beekmann M, Rouil L. Simulation of ozone during the August 2003 heat wave and emission control scenarios. Atmos Environ 2005; 39: 2957-2967.

(C) Martins and Andrade; Licensee Bentham Open.

This is an open access article licensed under the terms of the Creative Commons Attribution Non-Commercial License (http:/creativecommons.org/licenses/by$\mathrm{nc} / 3.0 /$ ) which permits unrestricted, non-commercial use, distribution and reproduction in any medium, provided the work is properly cited. 